UDC: 657:65.012.34

JEL Classification: M 41

doi: 10.31767/nasoa.1-2-2021.02

O. PYLYPENKO,

Dsc (Economics), Associate Professor, Professor of Accounting and Taxation Department, e-mail: olexiy17@meta.ua,

Researcher ID: $A \bar{A} Y-8242-2020$,

ORCID: https://orcid.org/0000-0003-3469-7742;

O. YURCHENKO, PhD (Economics),

Associate Professor of Accounting and Taxation Department; e-mail:alexdekan@ukr.net, ORCID: https://orcid.org/0000-0002-8447-6510; National Academy of Statistics, Accounting and Audit

\title{
The Accounting Support of the Logistics Strategy in Business Management for Security Purposes
}

The need in elaborating and implementing innovative decisions for performance enhancement of the logistics management in business enterprises has increased due to the high instability and uncertainty of business operation resulted from imposed quarantine restrictions due to the pandemic of coronavirus and fluctuations of exchange rates, which raises the importance of studies focused on improvements in the conception of accounting support of logistics operations from the business security perspective.

The essence of neologistics as an innovative vector in the logistics activities is shown, with highlighting the advantages gained by business enterprises from its implementation. The authors' framework of the accounting support for logistics operations on purchases of material assets and implementation of an innovative logistics strategy in business management for business security purposes is proposed. It is based on the three vectors of the integrated accounting support of the logistics strategy in business management: organizational vector, methodological vector, and vector of control. It is emphasized that the implementation of this framework is capable to increase the significance of criteria used in performance assessment of accounting, such as reliability, completeness, analytical relevance and timeliness of data. Factors were determined as part of this framework, allowing business enterprises that have implemented integrated planning, economic analysis, accounting and control of data processing to broaden the range of decisions on cost reduction in logistics without affecting the quality of products or services; the resulting modifications in the accounting objectives are given. It is shown how this framework, once implemented, will change the accounting practices of business enterprises pertaining to recording of logistics costs.

Keywords: logistics, neologistics, logistics strategy, logistics operations, logistics costs, accounting, accounting support.

О. I. ПИЛИПЕНКО,

доктор економічних наук, дочент, професор кафедри обліку і оподаткування;

О. А. ЮРЧЕНКО, кандидат економічних наук, доиент кафедри обліку і оподаткування; Національна академія статистики, обліку та аудиту

\section{Облікове забезпечення логістичної стратегії в управлінні підприємством для цілей безпеки}

Необхідність розроблення і реалізації інноваційних рімень з метою підвищення ефективності логістичного менеджменту на підприємствах зростає через значну нестабільність і невизначеність діяльності внаслідок запровадження карантинних

(C) O. Pylypenko, O. Yurchenko, 2021 
обмежень, пов'язаних із пандемією коронавірусу, а також валютних коливань, щуо обумовлює актуальність досліджень, спрямованих на вдосконалення концепиії облікового забезпечення логістичних операчій для иілей безпеки.

Розкрито сутність неологістики як інноваційного напряму логістичної діяльності, окреслено переваги, отримувані підприємствами від ї̈ використання. Запропоновано авторську концепцію формування облікового забезпечення логістичних операчій з придбання матеріальних активів і реалізації інновачійної стратегії логістики в управлінні підприємством для ијілей безпеки. Вона трунтується на трьох напрямах інтегрованого облікового забезпечення логістичної стратегії в управлінні підприємством - організаиіийнму, методологічному і контрольному. Підкреслено, щуо реалізація цієї концепиіі підвищує значущість таких критеріїв оиінювання ефективності бухгалтерського обліку, як надійність, повнота, аналітичність і своєчасність даних. В рамках иієї концепиії визначено фактори, завдяки яким інтеграчія планування, економічного аналізу, бухгалтерського обліку та контролю оброблення інформації розширить можслиості підприємства у виборі способів зниження логістичних витрат без втрати якості продукиї̈, а також перелік відповідних змін у завданнях бухгалтерського обліку. Розкрито характер змін завдань бухгалтерського облікущодо відображення логістичних витрат підприємства в разі реалізації концепиії.

Ключові слова: логістика, неологістика, логістична стратегія, логістичні операції, логістичні витрати, бухгалтерський облік, облікове забезпечення.

Introduction. The current trends in the Ukrainian economy affected by the crisis feature high instability and uncertainty of business operation due to the long time quarantine limitations caused by COVID-19 pandemic and currency fluctuations. In this adverse business environment there has been increasing demand for finding and implementing innovative decisions aiming to enhance the efficiency of logistics management system at company level.

Creating the conditions for building stable infrastructure and promoting comprehensive and sustainable industrialization and innovation, announced as a sustainable development goal of Ukraine in the Decree of the President of Ukraine No 722/2019 on Sustainable Development Goals of Ukraine till 2030 [1], requires adequate financing of innovations and their implementation in logistic services as part of the company operation. Advanced achievements used in management of material flows are aimed at the transition to rational models of production and consumption, the enhancement of business performance and the recovery of Ukraine from the economic crisis.

A matter of special importance is quick technology renovation of the logistics activities and essential reduction of low performing production technologies. From the theoretical viewpoint, the accounting support for the logistics component in business management is only partially relevant to the economic security objectives. Accounting data on numerous risks and effects of current business uncertainties for the performance indicators cannot be effectively supplied unless a radically new framework for the accounting data and their structuring for business management purposes is developed. Revisions and improvements are also required for schemes of information support to the innovative logistics policy, in order to make material flows more effective at the phases of production supply, process and completion. This determines the need in exploring potentials of accounting support in setting and implementing innovative logistics strategies in business management as a core factor of business security.

Literature review. Problems of using logistics for management of material assets in the business sector were subject to analysis in works of many researchers (B. Anikin, P. Drucker, A. Kalchenko, F. Kotler, Ye. Krykavskyi, V. Myroniuk, V. Omelchenko, M. Rumiantsev, N. Chukhrai and others). Problems of accounting support to business security management were dealt with in works of V. Bondar, M. Bondar, I. Bielousova, F. Butynets, L. Hnilitska, V. Zhuk, A. Zahorodnit, L. Kindratska, M. Korinko, M. Kropyvok, Ya. Krupka, S. Levytska, L. Lovinska, N. Maliuha, I. Mihus, Ye. Mnykh, V. Paliy, M. Pushkar, V. Savchuk, Ya. Sokolov, M. Chumachenko, V. Shevchuk. Their contribution lays the basis for integrating logistics and accounting as components of business security management in the difficult economic situation. But the accounting support to logistic operations is yet to be conceptualized from the business security management perspective.

The article's objective is to highlight the author's vision of the accounting support 
to logistics operations on purchase of material assets and implementation of an innovative strategy of logistics in business management for business security purposes.

Research results. Logistic activities of business enterprises were heavily hit in 2020: the production capacities had to reduce due to serious disruptions of normal relations between producers and consumers of goods and services, borders were closed, and the traffic volume fell due to limitations on the freight traffic flow. According to researchers, with the traffic volume on the European market declining by $40 \%$ or more, transport companies must have an elaborated package of anti-crisis measures with the adequate financial support $[2,3]$.

Given the extremely adverse economic environment, business management can be made effective by integrating accounting and management of material resources, especially logistics. It is believed that accounting can contribute in enhancing the performance of material supplies by increasing their cost-effectiveness, with positive effects for production costs and profits from sales. This integration is important because business managers tend to overlook or ignore logistic tools in management of material flows, and lack of feedback between accounting and logistics does not allow managers to have positive impact on purchases and subsequent uses of material resources, which, in the final end, prevents from cost saving and optimization of stocks given a high share of material costs in the cost structure.

Economic crises always posed stricter demands to the choice of options for the improvement of logistic strategies and even triggered the birth of an innovative area in logistics, neologistics [4, p. 118]. Factors determining this particular area in logistics were increased transportation costs, depletion of natural resource deposits, creation of new product lines, utilization of computer technologies, as well as radially new criteria of social, technological and environmental components of the business operation.

The essence of neologists is that it can change long-term development prospects of a business enterprise by using the system approach to the materials' flows and the trade-off theory. Due to the implementation of neologistics, logistic systems of business enterprises could have implications for innovations in social, technological and environmental spheres.

According to professor M. S. Pushkar [5, p. 263], neologistics can reduce operational costs and funds invested in storage and movement of assets in a way allowing to achieve the sustainable development of a business enterprise. In the business environment faced by Ukraine and other countries, neologistics has to improve the services and increase the speed of supplies on the basis of professionalization of logistic activities. The survival on transport markets and the sustained competitiveness is attainable for the business enterprises that will be able to reduce fixed and variable costs with the least losses for business, and to enhance the quality of client services through diversifying the range of logistic services.

The costs of logistic operations, including placement of orders for supplies, purchases, storage, transportation of materials, intermediate storage and warehouses storage of products, shipments, transportation to buyers, after-sales services etc. are exposed to a great many risks. The latter occur due to growing purchase prices and fuel prices, spoilage of goods, inadequate quality of goods, increasing demand for goods, damages of cargo goods in time of transportation. An essential factor of risk has been quarantine limitations due to COVID-19 pandemic, making the business environment uncertain for a long term. The above mentioned raises the importance of effective management of the risks creating an obvious threat on the basis of accounting information.

The impact of risks on the logistics costs needs to be estimated on the basis of reliable, complete, timely and analytical accounting information. We share the viewpoint of T. Khlevytska that the logistics is a means for combatting risks that occur in trade businesses [6, p. 310]. It follows that the function of accounting with respect to the logistics performance enhancement is documentary fixation of violations of the terms of transportation of stocks, the cases of overstocks, the losses resulting from negligent storage and use, violations of obligations fixed in client contracts. The function of accounting related with recording of logistic operations with purchased production stocks will be facilitated by its incorporation in the accounting policy of a business enterprise.

Integration of the accounting support to logistics for business management purposes, being a core component of the secure business operation, has to be three-dimensional:

1. Organization: (i) improving the communicational integration of accounting unit, logistic unit, security unit, internal control unit, planning and analytical units; (ii) regulating 


\section{The Accounting Support of the Logistics Strategy in Business Management for Security Purposes}

the responsibilities of staff pertaining to economic security management; (iii) protecting the data contained in online documentation; (iv) designing a protection scheme for the data making confidential information or commercial secret, for the contract services provided by logistic companies.

2. Methodology: (i) choice of the costing methods that can optimize the costs of logistics in purchase and utilization of production stocks; (ii) using tax clauses to minimize the risks of logistics strategy implementation; (iii) a complex model for risk management in logistics as part of the business process control system.

3. Control: (i) designing methods for internal control of business staff's communications in the secure environment on the basis of effective document circulation and internal reporting; (ii) methodical recommendations on organization and performance of inventory; (iii) a set of measures for protection of data on stocks (prices, quality, assortment, suppliers, purposes, etc.).

The proposed framework for decision-making on material flows and their financing cannot be implemented unless the respective requirements to accounting are met, such as reliability, completeness, analytical value and timeliness of data. The latter becomes even more valuable considering that accounting data on logistic operations are used for forecasting of logistics activities.

The operational data on costing contained in internal business reports and the abilities of logistics unit staff to use them for assessments of alternative options in purchases of stocks lays the basis for effective stock management, cost saving and profit making.

To perform the logistics functions on optimization of financing of material flows, the accounting manual needs to include a method of building analytical data sets with compilation of internal reports by the following categories of costs: purchase, production, distribution and sales, formation of acquisition cost, storage, transportation, information service.

The optimization of logistics costs can be facilitated by using appropriate costing methods. The production cost, an essential measure providing a comprehensive characteristic of change in technology, labor and production pattern, is an indicator of profitability and a factor of performance enhancement in a business enterprise. Implementation of cost optimization methods has critical importance for business enterprises in the conditions of economic crisis.

Given the adverse economic environment in Ukraine along with continuously growing prices for raw materials and fuels, and currency fluctuations, the high production cost is a factor impeding effective operation, reducing market segments and shrinking the client base. Choices and applications of new methods for costing can help optimize material and financial flows, making businesses more flexible and highly performing even in unfavorable economic environments. Also, special attention needs to be drawn to issues of tax clauses in minimizing the risks involved in the implementation of logistics strategies, and to the use of accounting data in management of logistics risks as part of the business process control system.

Once the procedure of business staff interactions, specified in the accounting policy of a business enterprise, relies on proper technical and methodological support of accounting, the effective information support of logistics functions based on the accounting data can be achieved.

We believe that the description of the proposed dimensions of the framework for accounting support to logistics activities will help improve the toolkit of comprehensive accounting support to the logistics management for security purposes. Integration of planning, economic analysis, accounting and control over data handling will widen the choices of cost reduction methods for a business enterprise without affecting the quality of products due to:

- availability of sound estimated data to be used in negotiations with suppliers and buyer for optimization of pricing or setting trade margins;

- availability of client development programs and the optimal contractual policy of a business enterprise;

- integration of information data in the relevant computer program, allowing to enhance the overall efficiency of logistics cost management;

- ability to find less costly substitutes of resources without affecting the quality of products;

- ability to coordinate operations of a business enterprise and its counterparts, to provide for timely deliveries of stocks and optimize the costs of warehouse stock movement and 
stock management;

- implementation of innovative methods in business, in order to enhance the labor productivity and the operation performance at unit level;

- identification of the categories of cost-ineffective activities through analyses and revisions of supply chains with reference to the current contractual policy of a business enterprise.

The implementation and control of the abovementioned schemes in building an economic security management system will modify the functions of accounting related with recording of logistics costs. It is important that the accounting data on logistics costs allow for:

- analytical computations (through extending a set of analytical indicators estimated by use of accounting data, including analytical breakdown of logistics costs);

- the preventive nature of control aimed at the avoidance of abuse, crises and threats to the economic security, including the ones provoking logistics risks;

- the creation of a database for the economic security management system (broadening the coverage of management objects by including meeting of information demands of the staff responsible for the logistics strategy implementation through making up internal business reports at various phases of the purchased stock movement; optimizing the logistics costs related with purchases and uses of production stocks through the choice of costing methods; building the interactions of business staff on effective document circulation, specified inventory procedures, protection of data on stocks, etc.).

Conclusions. Given essential problems of economic management in the business enterprise sector as a whole and management of material resources in particular, the need for finding more effective tools for stock management on the basis of logistics is highlighted. It is demonstrated that a theoretical and methodological framework for the accounting support of logistics in business management has to be based on the integration of the accounting system and other management functions (planning, economic analysis and control), which is supposed to focus the accounting support of logistics on the enhancement of economic security of a business enterprise.

A three-dimensional framework (organization, methodology, and control) for the integrated accounting support to the logistics strategy in business management is proposed, with outlining the modifications in accounting objectives, involved in this framework. The value of such modifications can be explained by their critical significance for economic security management of business enterprises in the current economic environment.

\section{References}

1. Pro Tsili staloho rozvytku Ukrainy na period do 2030 roku [The Sustainable Development Goals for Ukraine till 2030]: Decree of the President of Ukraine No 722/2019. Retrieved from https://www.president.gov.ua/documents/7222019-29825 [in Ukrainian].

2. Kobylyukh O. Ya, Hirna O. B., \& Hajeva L. I. (2020). Kliuchovi aspekty transportnoi lohistyky v umovakh pandemii COVID-19 [Key aspects of transport logistics during the pandemic COVID-19]. Vcheni zapysky TNU im. V.I. Vernadskoho. Seriia: Ekonomika i upravlinnia - Scholarly notes of V. I. Vernadsky Taurida National University. Series: economics and management, vol. 31(70), issue 4, 117-122 [in Ukrainian].

3. Plan poriatunku: chy mozhe Ukraina nalahodyty efektyvnu lohistyku [A rescue plan: can Ukraine set up an effective logistics?]. Retrieved from https://mind.ua/ publications/20179078-plan-poryatunku-chi-mozhe-ukrayina-nalagoditi-efektivnulogistiku [in Ukrainian].

4. Panasenko Ye. V. (2011). Logistika: personal, tekhnologii, praktika [Logistics: personnel, technologies, practice]. Moscow: Infra-Inzheneriya [in Russian].

5. Pushkar M. S., Bohach A. H., \& Melnyk V. H. (2007). Lohistychni systemy pidpryiemstva: oblik, analiz i audyt [Logistics systems of the enterprise: accounting, analysis and audit]. Ternopil: Ekonomichna dumka [in Ukrainian].

6. Khlevytska T. (2002). Lohistyka yak zasib upravlinnia asortymentnym ryzykom torhovelnykh pidpryiemstv [Logistics: a means for management of the assortment risk at trade companies] Torhivlia i rynok Ukrainy - Trade and market of Ukraine, vol. 2, issue 13, 309-314 [in Ukrainian]. 
Bibliographic description for quoting:

Pylypenko O., Yurchenko O. (2021). The Accounting Support of the Logistics Strategy in Business Management for Security Purposes. Scientific Bulletin of National Academy of Statistics, Accounting and Audit - Naukovyy visnyk Natsionalnoi akademiyi statystyky, obliku ta audytu, 1-2, 14-19. doi:10.31767/nasoa.1-2-2021.02. 